\title{
Doğu Batı Arasında İki Mütereddit: Ahmet Hamdi Tanpınar ve Oğuz Atay
}

\author{
Between East and the West Two Ambivalent Figures: \\ Ahmet Hamdi Tanpınar and Ŏguz Atay
}

\section{Zafer DOĞAN*}

Öz: Bu makale edebiyatımızın çok tartışılan iki yazarı olan Ahmet Hamdi Tanpınar ve Oğuz Atay'ın geçmiş ile bugün veya daha doğru bir ifadeyle gelenek ile modernlik arasındaki kırılmayı nasıl ele aldıkları sorusuna cevap aramaktadır. Atay ve Tanpınar Türk edebiyatında Doğu-Batı meselesinde alışılagelen yaklaşımları sorgulayarak ve aşarak; yeni bir perspektif getirdiler. Her iki yazarın Türk edebi geleneği içerisindeki ayırt edici özelliği geçmiş ve bugün arasındaki kırılmanın giderilmez bir kopukluk doğurduğunun farkında olmaları ve bu kopukluğun yarattı̆̆ı durumları kimi zaman hüzünle kimi zaman da ironiyle işleyerek edebi yaratıcılıklarının beslendiği bir kaynak haline dönüştürebilmeleridir. Onlar hep bir endişe kaynağı olan bu kopukluğu aşmayı amaçlamazlar. Geleneğe dönülemeyeceğinin farkındadırlar. Modern olanı tereddütsüz benimsemenin getireceği yüzeyselliği ve yarattı̆̆ kimlik kaybını ise reddederler. Tam da bu yüzden bu mütereddit hali yeni bir kararlılık haline getirip bu konuda yeni bir hesaplaşma biçimi önerirler. O güne kadar sentez fikriyle aşılmaya çalışılan Doğu-Batı meselesi artık onların romanlarında çözüm getirilmesi gereken bir mesele değil; edebiyatlarına hakiki bir ses kazandıran bir güce dönüşür. Makale hazırlanırken, Ahmet Hamdi Tanpınar ve Oğuz Atay'ın Doğu-Batı ilişkisini ele alışları incelenmiş ve her iki yazarın kimlik ve medeniyet anlayışı saptanmıştır. Bu saptamadan sonra, bu yazarların kimlik ve medeniyet anlayışlarındaki benzerlikleri ve farklılıkları makalede gösterilmiştir.

Anahtar sözcükler: Doğu-Batı Sorunu, Kimlik Endişesi, Modernleşme, Edebi Özerklik, Mazi

Abstract: This article explores the question of how two highly controversial writers of Turkish literature approach the rupture between the past and the present, or more precisely, between tradition and modernity. Atay and Tanpınar brought a new perspective to Turkish literature by questioning and overcoming the usual approaches to the East-West issue. What distinguishes them in the Turkish literary tradition is the awareness that the rupture between the past and the present creates an unbridgeable gap and the way they handle the symptoms of this gap at times with sorrow, at times with irony, transforming it into the resource that their literary ingenuity draws upon. They do not aim to move beyond the void which is a continuous source of anxiety. They are aware of the impossibility of going back to tradition. They also reject the superficiality and lack of identity brought on by identifying without hesitation with the modern. That is precisely why they transform their ambivalence into a new consistency, suggesting another form of confrontation. The East-West divide is not a problem to be resolved in their novels. Formerly a matter to be overcome through the idea of synthesis, this issue becomes the power that gives their literature a genuine voice. In the process of the article preparation, Ahmet Hamdi Tanpınar and Oğuz Atay's treatment of the relationship between the East and the West was thoroughly researched and their approaches to the concepts of identity and civilization were determined. Following this, the similarities and differences between the two authors' conceptions of identity and civilization are presented in this article.

Keywords: The East-West Problem, Anxiety over Identity, Modernization, Literary Autonomy, the Past

\footnotetext{
* Öğr. Gör. Dr., Yıldız Teknik Üniversitesi, Atatürk İlkeleri ve İnkılap Tarihi, İstanbul. zaferdoganytu@hotmail.com
} 
Türkiye'deki roman geleneğinin ağırlıkla Doğu-Batı izleğinin ekseninde kurulması, bu alandaki kafa karışıklıklarının ve tereddütlerin halen ülkemizdeki düşünce dünyasının ana meselelerinden birisi olagelmesi tesadüfî değildir. Modernleşme sürecinin yarattığı kültürel çatışmalar düşünülmeden kimlik meselesinin tam olarak anlaş1labilmesi imkânsızdır. Türkiye'deki edebiyat geleneği kimlik meseleleri üzerinden yaşanan bu çatışmayı merkezi bir tema olarak değişik yönleriyle işlemiştir. Kuşkusuz bunu estetik düzeyde en yetkin şekilde yapan ilk romancilar Ahmet Hamdi Tanpınar ve Oğuz Atay oldu. Her iki yazarın halen çok tartışlıyor olmasının sebebi kimlik ve mazi sorununda almış oldukları özel konumla açıklanabilir ancak. Yine her iki yazar Tanzimat'tan Cumhuriyet dönemine intikal eden “Batı'nın teknolojisini alalım, kültürümüzü muhafaza edelim” formülüyle dile getirilen oksidantalist söylemin yüzeyselliğini aşmayı başardılar. Bu anlamda Doğu-Batı çatışmasının beraberinde getirdiği endişelerin, tereddütlerin ve kimlik hesaplaşmalarının Tanpınar ve Atay romanlarında çok özel yeri vardır. Bu tereddüt ve endişe halini "aşmayl" değil; bu hali sürekli kılacak bir konumu estetik yaratıcılıklarının kaynağ 1 haline getiren bir tutuma sahiptirler. Geçmişle yaşanan kopuş, bu yazarların edebi dünyasında değişik biçimlerde işlense de bu özel tutumun bir ortaklık yarattı̆̆ını söylemek mümkündür. Oğuz Atay'ın romanlarında geç modernleşmenin yarattığı çelişkilerin yol açtığı ironiyi anlatmaya çalışmasıyla; Ahmet Hamdi Tanpınar'ın geçmişin estetik ve tarihsel birikimini romana dâhil etme girişimleri arasında bir paralellik söz konusudur. Çağdaş Türk edebiyatı kanonunun içinde yürütülecek bir kimlik tartışmasının bu yazarlar olmadan yapılamıyor olması anlamlıdır (Kanon kavramının kullanımı Antikçağa kadar dayansa da esas olarak bugünkü kullanım anlamına, tavsiye edilen, okunması gereken kitaplar listesi, Hıristiyan teologlarının İncil üzerine yaptıkları incelemelerde referans kitaplar oluşturulması fikriyle doğmuştur. Edebi kanon ise bir ulusun kültürel birikiminin en temel yönlerini yansıtma özelliğine sahip olan külliyat demektir. Bu açıdan bir kanon toplumlar için hangi kültürel ürünlerin önemli olduğunu belirler. Bu konuda ayrıntılı bilgi için bakınız: Mihály-Szegedy 2001, 16-17). Tanpınar ve Atay'ın modernleşme ve kimlik konusunda dile getirdikleri, Türk edebiyatında yeni bir bakış açısı yarattı. Her iki yazarın en büyük benzerlik noktası kimlik ekseninde toplumsal ve bireysel anlamda yaşanan büyük gerilimi, estetik bir kaynağa dönüştürebilmeleridir.

\section{Tanpınar ve Mazi}

Tanpınar ara kuşaktır. Osmanlı İmparatorluğu'nun son yıllarına ve Cumhuriyet'in ilk dönemine şahit olmuş ve yitip giden ile yeniye duyulan arzu arasındaki karmaşık çatışmayı edebi estetiğin kaynağı haline getirmiştir. Eserlerinde en çok kullandığı anahtar kelime "mazi”dir. Temel sorun, mazi ile bugün arasında ilişkinin nasıl kurulacağı üzerinedir. Edebi açıdan geçmiş ve bugün arasında belli bir melankoli ve ikilem olmadan bunun yapılabilmesi zor gibidir. Tanpınar'da bu durumun yol açtığı gerilim kendini derin bir şekilde hissettirir. Mazi ile yeni arasındaki giderilmez kopukluk durumu onun edebiyatının merkezinde durur. Bütün yapıtlarında şu soruyla karşılaşırız: Yeniyi şevkle kabul ederken maziyi yok saymadan, bu keskin kopuşla nasıl baş edilecektir?

Açıkçası Tanpınar bu sorunu sadece düzyazılarında değil romanlarında da sıkça tartışır ve tartıştırır. "Huzur"da romanın karakterleri kendi aralarında tarım, sanayi, felsefe, üretim, iktisadi durum, aydın-halk çelişkisi, müzik, resim gibi konuları Doğu-Batı meselesi bağlamında uzun uzadiya konuşurlar:

“Vâkıa bugün nisbî bir rahat içindeyiz. Orta Avrupa'ya iktisaden kendimizi bağlamışı; klering hesabıyla, şununla, bununla geçinip gidiyoruz. Fakat bu muvazaa ylkılabilir, o zaman ne yapacağız?.. Fakat asıl mesele bu değil, asıl mesele topră̆ ve insanı hayatımıza sokamamakta. Kırk üç 
bin köyümüz var; birkaç yüz kasabamız var. İzmit'ten öteye Anadolu'ya açılın; Hadımköy'den öteye Trakya'ya gidin. Birkaç kombinenin dışında hep eski şartların devamını görürsünüz. Coğrafya yer yer esniyor. Sikı bir nüfus siyasetine, sıkı bir istihsal siyasetine başlamamı lâzım. (...) Yarı zirâ̂, yarl sinaî bir iş hayatı temin edebiliriz. O kadar hususî istihsal kaynaklarımız var ki... İşse İstanbul. Daha dün bir yüksek müstehlikler şehriydi. (...) Halbuki İstanbul'da planlı bir çalışma, cemiyetimizin yüzünü yirmi senede değiştirebilir. Al Şarkî Anadolu'yu. Ziraatle, hayvancılıkla muazzam imkânlar hazinesi görürsün! Tortum şelâlesinden işe başla. Kademe kademe Akdeniz'e kadar elektriği indir... Marmara serveti içine gömülmüş uyuyor" (Tanpınar 2010, 248).

Kurguya yamanmış bu fikir pasajları romanlarının estetik yapısını fazlasıyla zedeler. Hâlbuki onun edebiyatının asıl güçlü yanı bu fikir pasajlarında değil, maziye doğru çıkılan yolculukların, hatıralarla yüklü eşyaların ve zamanın bıraktığı izlerin anlatıldığı bölümlerde saklıdır. Ancak bu zaafa rağmen Doğu-Batı ve kimlik konusundaki meseleleri, çözüme kavuşturmaya çalışmaktan çok kafa karışıklığı içinde olması, bu durumu estetik bir imkâna dönüştürerek kesin hükümlerden kaçınması, onun tereddüt halinin bilinçli olduğunu ve modern bir konum içerisinde kald1ğını gösterir. Tanpınar düşünce, tutum ve içerikte modern bir bilinçle hareket ederken; estetik düzeyde modernist olamamıştır. Bunun için Oğuz Atay’ı beklemek gerekecektir.

Maziyi metaforik olarak bir tür eski konağa benzeten Tanpınar, mazi ile bugün arasındaki ilişkiyi şöyle betimler:

"Sen o hatıralar için yaşarsın. Mucizenin kendisi değilse bile, ondan her yana sinen sir vardır, emniyet vardır. Aradı̆̆ını bulmasan bile aramanın zevkini duyarsın. Sonra bir an gelir, konağın kendisi yanar. Şimdi enkaz arasında gördü̈̆̈̈müz insanlara benziyoruz. Bir yığın kül, kararmış direk, pasl demir, yer yer duman, is ve çamur içinde işte bulunduğumuz şey... Şimdi sen istediğin kadar bu artıklarla yeni bir şey yapmaya çalış; istediğin kadar şarkl, eski dünyamızı sev, ona bağl yaşa; sihirli nefes ortadan kaybolduktan sonra elindeki çerçöp yığınından ne çıkar? Hatta hatıranda kalan şey bile bir işe yaramaz" (Tanpınar 2005a, 91).

İmparatorluk geçmişini çağrıştıran konak yanmıştır ve bu yangın yerinin küllerinde eşelenmek belki de boşunadır. Ama önemli olanın "aradığını bulmasa bile aramanın zevkini” duyabilmek olduğunu anlayan ve bunu sanatının bir çeşit pusulası haline getirebilen Tanpınar, bu yangın yerinden sanatsal ruhunun ve yaratıcılığının esaslı bir temelini bulur. Tanpınar'ı modern kılan tam da bu özelliğidir. O yitip giden Şark dünyasına ve maziye bir Garplı gibi bakabilmeyi öğrenmiştir. Kaybolan geçmişi bulmaya ya da diriltmeye çalışan bir tutumdan ziyade geçmişin geri gelmeyeceğinin farkında olan ve bu farkındalık üzerinden geçmişi, estetiğinin merkezine yerleştiren bir bilinç söz konusudur. Yani bizzat bu arayış halinin kendisine odaklanmış bir bilinç söz konusudur Tanpınar'da. Bu durum aynı zamanda Erken Cumhuriyet döneminde güçlü olan ve sanata misyon yükleyen angaje edebi anlayıştan kopuşun gerçekleşmeye başladığını da gösterir. Türkiye'de edebiyatın ve düşünce dünyasının büyük ölçüde Doğu-Batı, aydın-halk ya da ezen-ezilen gibi çatışmalı ikilikler üzerine inşa edilen yapısında çoğu zaman çözüm öneren tezli edebiyat geleneği yerine edebiyatın kendi başına bir amaç olduğu, özerkliğini kazanmaya başladığı noktaya gelmiş oluruz. Bu da Tanpınar'daki estetik kusurları bir nebze hafifletir.

Tanpınar, kültürel bir ikilemin ve çatışmanın ortaya çıkardığı bunalımın içerisinde estetik 
varoluşuyla Türk romanının ana halkalarından birisini oluşturur. Kendi konumunu "Hülâsa bir yığın tezadın adamıyım" diye tanımlarken fikir ve sanat meselelerinde yaşadığı gelgitleri, kafa karışıklıklarını anlatmak ister gibidir (Tanpınar 2008b, 333). Tanpınar sadece söylemde değil, yazarlık kariyeri boyunca da birbiriyle çelişen tezler ve fikirler dile getirmiştir. 1930'larda divan edebiyatının ortaöğretim müfredatından kaldırılmasını öneren sanatçı, 1940'larda klasik Osmanlı kültürüne ve şiirine geri dönülmesini savunmuş, hayatının sonlarına doğru ise bizde Batı ile boy ölçüşebilecek bir eserin ve klasik kültürün olmadığını söylemiştir (Ayvaz 2006, 153).

Yıkılan bir imparatorluğun ve ondan arta kalan bir ulus devletin yarattığı bütün tezatlar, bunalımlar onun estetiğinde yer bulur. Tanpınar ne basit bir Doğu-Batı ikilemini işleyen bir yazar, ne de gelenekçi yaklaşımın bir temsilcisi olarak değerlendirilebilir. Bu açıdan Batı'nın karşısına Doğu'yu ikame eden metafizik söylemlerden ısrarla kaçınmış, maziyi tarihselci bir çerçeveden anlamaya çalışmıştır. Maziye bakarken her neslin kendi tarihsel şartlarının bir ürünü olduğunun farkındadır. Tanpınar aynı zamanda nostaljik ya da idealize edilmiş romantik geçmiş anlayışına karşı da mesafeli duran bir yazardır. Osmanlı geçmişinin altın çağına sığınmamıştır. Öbür yandan cumhuriyetin ilk yıllarında Osmanlı geçmişini reddeden, kültürel kimliği sadece Orta Asya tarihinde ya da eski Anadolu medeniyetlerinde arayan yaklaşımı da benimsememiştir. Tanpınar'ın karşı olduğu Tanzimat'tan beri devam edegelen yüzeysel ve biçimsel Batıcılık anlayışıdır. Bu tür kültürel kimlik yaklaşımını fazlasıyla yavan ve sığ bulan Tanpınar, Osmanlı siyasal mirasını değil; kültürel geçmişinin derinlikli ve incelikli tarafını sahiplenir.

Tanpınar'ın kimlik endişelerini ve mazi konusundaki mütereddit halini anlayabilmek için Türkiye'deki erken dönem milliyetçilik anlayışını ve bunun Osmanlı geçmişi ile kurduğu ilişkiye bakmak gerekiyor. Cumhuriyetin kurulmasıyla hayata geçirilmeye çalışılan ulusçu yönelim neticesinde yeni bir tarih görüşü inşa etmek için 1930 tarihinde Türk Tarih Tetkik Cemiyeti kurulmuştur. İlk Türk Tarih Kongresi'nin en önemli gündem maddesi Türk ulusunun kökenlerinin nereye dayandırılacağı meselesi üzerinedir. Afet İnan'ın kongrede sunduğu tebliğde şu görüşlere yer verilmiştir: "Türk ırkl, ana yurtlarında, yüksek kültür mertebesine varırken, Avrupa halkı vahşi ve tamamen cahil bir hayat yaşlyordu;... Orta Asya'nın otokton halkı Türktür (alkışlar). Türk çocukları biliyor ve bildirecektir ki, onlar, 400 çadırlı bir aşiretten değil, on binlerce yıllık, Ari, medeni, yüksek bir ırktan gelen, yüksek kabiliyetli bir millettir”. (Ersanlı 1995, 130). Öbür taraftan hem Sevr travmasının etkisi hem de Anadolu ile ilgili Yunan ve Ermeni tarih tezlerine cevap verebilme kaygısıyla Anadolu'nun eski medeniyetleri Türklerle ilişkilendirilmiştir. Erken Cumhuriyet döneminin milliyetçi/pozitivist tutumundan kaynaklı olarak Türk Tarih Tezi, Osmanlı tarihine adeta gözlerini kapamış; bunun yerine İslamiyet öncesi Türk tarihine yönelmiştir. Bunun anlamı Osmanlı geçmişinin devlet söyleminde bir kültürel kimlik inşa etme unsuru olarak büyük ölçüde dışlanması demektir. Osmanlı kozmopolitliğine yapılan eleştirinin temelinde homojen, seküler bir ulus inşa etme dürtüsünün rol oynadığını görüyoruz. Ancak asıl sebebi Osmanlı millet sistemine duyulan tepkide aramak gerekiyor. Cumhuriyet kurucuları Osmanlı'yı bir Türk devleti olarak görmüyorlardı ve İslam milleti adı altındaki diğer unsurlarla (özellikle Arap) olan farklılığın altını çizerek ulusal kimliğin öne çıkarılması suretiyle bir çözüm üretmeye çalışıyorlardı. Bu ayrışmayı gerçekleştirmek amacıyla yeni bir ve kültür ve dil politikasını hayata geçirmeye çalıştılar.

Fransız Devrimi ve modern devlet modelinden etkilenen Jön Türkler kuşağının son halkası Kemalizm, Osmanlı İmparatorluğu ve İslam kültürüne mesafeli yaklaşarak seküler milliyetçi bir ideolojiye dayanma ihtiyacı duydu. Kurulan yeni devletin siyasi seçkinleri Batı karşısında gelinen durumun müsebbibi olarak gördükleri Osmanlı ve İslam geçmişine mesafeli yaklaşmayı tercih ettiler. Tanpınar kimlik ve tarih görüşü noktasında belli ölçüde Kemalizmin bu yakla- 
şımından ayrı düşmüş bir aydındır. Ancak diğer taraftan siyasal planda zannedilenin aksine Tanpınar'ın DP'ye yönelik son derece sert eleştiriler yönelttiğini, hatta bunun 27 Mayıs Darbesi'ne destek vermeye kadar vardığını yıllar sonra gün yüzüne çıkan günlüklerinden öğreniyoruz (Tanpınar 2008b, 213-214).

Yeninin fetişleştirildiği ve yitip gidenin unutulmak istendiği bir dönemde yaşayan Tanpınar, soğukkanlı yaklaşımıyla dikkat çeker. Mazinin tümden reddinin bir kültürel fakirleşme demek olduğunun pekâlâ farkındadır. Bu yüzden kaybolan mazinin izlerinin sürülmesi sadece estetik bir imkân değil; aynı zamanda kültürel fakirleşmeye karşı sessiz bir direnişi de ifade eder. Tanpınar'ı edebiyat geleneğimiz içerisinde farklı kılan en önemli özelliği çağdaşlarından farklı olarak yüzeyde dolaşmakla yetinmeyen, kolaycı formül ve ezbere çözümlere yüz vermeyen bir yazarlık tutumuna sahip olmasıdır. Onu yaşadığı devirde silikleştiren; ölümünden sonra ise revaçta kılan mazi ve şimdi arasında kopan devamlılık zincirinin üzerinde düşünme biçimidir.

Tanpınar Doğu-Batı çatışması olarak görülen, çoğu durumda "teknolojisi gelişmiş ama manevi yönden eksik" şeklinde tanımlanan Batı medeniyetine karşı Doğu'nun erdem ve fazilet derslerini vermez. Mana-madde ikilemi üzerinden kurulan şematik oksidentalist yorumlara tenezzül etmez. Tanpınar Doğu-Batı meselesinin ne kadar karmaşık olduğunu, iki medeniyeti de tanıyan ve Batı'da olmanın bir seçim değil zorunluluk olduğunu ve bu zorunluluğun da pekâlâ korkulacak bir şey olmadığının farkında olan bir yazardır:

"Niçin Boğaz'dan ve İstanbul'dan bahsederken bütün bu dirilmesi imkânsız şeylerden bahsettim. Niçin geçmiş zaman bizi bir kuyu gibi çekiyor? İyi biliyorum ki aradĭ̆ım şey bu insanların kendileri değildir; ne de yaşadıkları devre hasret çekiyorum. IV Mehmed'in saltanat kayığının bir masal kuşu gibi altın ve mücevherlerden pirtl pirll, lacivert sulart yırta yırta Kandilli'ye yanaştı̆̆ını görmek yahut doğduğum yılların İstanbul'unda bir ramazan sergisinde- başımda fes, sırtımda pardesü, bir elimde kuka tespih, öbüründe ucu altın sapl baston ebediyete Ahmed Rıza Bey'in tasvirlerinden yadigâr kalan çok düzgün kesilmiş bir sakalla- birbirine karışmış gül yă̆g, tarçın yağl, her türlü baharat kokusu içinde dolaşmak, beni ne dereceye kadar tatmin edebilir? Hatta Kanuni'nin, Sokullu'nun İstanbul'unda bile on dakikadan fazla yaşayamam. Böyle bir şey için ne kadar kazanca göz yummak, benliğimden ne mühim parçaları kesip atmak lazım (...) Hayır aradığım şey ne onlar, ne de zamanlarldır" (Tanpinar 2008a, 206).

Tanpınar neden böyle hissettiğini de izah etmektedir:

"En büyük meselemiz budur; mazi ile nerede ve nasıl bağlanacă̆ız, hepimiz bir şuur ve benlik buhranınin çocuklarıyız, hepimiz Hamlet'ten daha keskin bir 'olmak veya olmamak' davası içinde yaşıyoruz. Onu benimsedikçe hayatımıza ve eserimize daha yakından sahip olacağız. Belki de sadece aramak ve bütün kapllarl çalmak kafidir... En iyisi, bırakalım hatıralar içimizde konuşacakları saati kendiliklerinden seçsinler. Ancak bu cins uyanış anlarında geçmiş zamanın sesi bir keşif, bir ders, hulasa günümüze eklenen bir şey olur. Bizim yapacağımız yeni, müstahsil ve canlı bugünün rüzgârına kendimizi teslim etmektir. O bizi güzelle iyinin, şuurla hulyanın el ele vereceği çalışkan ve mesut bir dünyaya götürecektir” (Tanpınar 2008a, 207-208). 
Sonuçta Tanpınar Batı'ya değil, geçmişin mirasını tümden reddeden bir Batılılaşma anlayışına karşıdır.

Öbür taraftan Tanpınar bütünlük arayışı içerisinde bir yazar olarak geçmişi kurgularken yitip giden ve bir daha gelmeyecek olanları bir topluluğun bütünlüğünün kayboluşu olarak tasavvur eder:

"Mahallenin kendisi de kayboldu (...) Bugünün mahallesi artık eskiden olduğu gibi her uzvu birbirine bağll yaşayan topluluk değildir; sadece belediye teşkilatının bir cüzü olarak mevcuttur. Zaten mahallenin yerini yavaş yavaş alt kattaki üsttekinden habersiz, ölümüne, dirimine kayıtsız, kü̧̈ük bir Babil gibi, her penceresinden ayrı bir radyo merkezinin nă̆mesi taşan apartman aldı (...) eski İstanbul mahalleleri artık sadece bir hatıradır. İsin garibi, onlarla beraber toplu yaşamayl, toplu eğlenmeyi de kaybettik" (Tanpınar 2008a, 130-131).

Tanpınar'ın Doğu-Batı ve kimlik meselelerindeki ikilemeni çok iyi yansıtan bir pasaj bu. Yitip giden mahallenin karşısında kompartımanlara bölünmüş ve daha bireysel hayatı simgeleyen apartmanın varlığı içten içe Tanpınar'ı tedirgin eder. "Saatleri Ayarlama Enstitüsü” ve başka birçok eserinde tasvir ettiği köşk hayatı, bireyselliğe ve özel hayata müsaade etmeyen; cemaat halinde ve onun değerleriyle yaşamayı mümkün kılan mekânlardır. Cemaat bağlarını zayıflatan çok dilli ve kozmopolit şehir hayatını anlatmak için kullandığı "küçük Babil" imgesi ise bu tedirginliği onun dilinden en veciz şekilde ifade etmektedir. Müşterek hayatın sürdüğü ve henüz sınıf ayrımlarının çok fazla derinleşmediği bir toplum imgesi Tanpınar'da moderni kabullenme ile birlikte bir tereddüdü de beraberinde getirir. Tanpınar maziye ilişkin bu ikircikli tutumunu: "Ne ondan kurtulabiliyorum, ne de tamamiyle onun emrinde olabiliyorum" diyerek özetler. (Tanpinar 2005b, 53).

Tanpınar'daki "mazi hasreti”, "bütünlük arayışı”, kendi olma isteğinin eserlerinde sık sık karşımıza çıkması bu yargıyı güçlendiriyor gibi görünüyor. Ancak unutmamak gerekiyor ki Tanpınar'ın "medeniyet değiştirmek" olarak tanımladığı meselenin merkezinde duran Osmanlı/ Doğu geçmişi, iç âleminde onu besleyen estetik kaynağın bizzat kendisine dönüşür. İmparatorluk çökse de, şaşaalı geçmiş yitip gitse de bu çöküşün kendisine takılıp kalmak yerine bu durumun ortaya çıkardığı estetik imkânları değerlendirme peşindedir: "Ben bir çöküşün esteti değilim. Belki bu çöküşte yaşayan şeyler arıyorum. Onları değerlendiriyorum...” (Tanpınar 2010, 172). Tanpınar bir daha maziye dönülemeyeceğinin, bu kopukluğun giderilemeyeceğinin farkındadır ve bu farkındalığıyla muhafazakâr gelenekten ayrılır. Tanpınar, modern olanın kendi bilincini yarattığını bilmektedir ve bundan şikâyetçi değildir. Tanpınar'daki tereddüt halinin nedeni bambaşkadır. Modernde karar kılmış; ama geçmişi toptan reddeden bir modernliğe eleştirel duran; diğer yandan ise yeni olanı özümsemekte istekli olan bir konumun gelgitleri vardır onda. Tanpınar, söylemindeki bütünlük arayışına rağmen sanatının gücünü mazi ve şimdi arasındaki bölünmüşlükten alan ve bunun bilincinde olan bir yazardır. Nurdan Gürbilek, Tanpınar'ın bu konumunu şöyle izah eder:

"Evet, bir mazi hasreti, kişinin ya da ulusun çocukluğuyla ilişkilendirilmiş bir tamlık hayali; bir eve dönme, kendine dönme israrı var Tanplnar'da. Ama diğer yanda 'kendi' denen yerin başından bu yana kayıpla şekillendiğini, bütün bu içeriklerin çoktan kaybedildikleri için yazıya dökülebildiğini söyleyen de odur. Kurumuş pınar, kayıp Şark ya da ölü anne: kaybedilen bundan böyle ancak 'hasretin kuvvetiyle', 'sözün kud- 
retiyle', bu kez bir iç dünya olarak kurulabilecektir. Tanpınar'ı siyasi muhafazakârlıktan olduğu kadar mazinin sahiden diriltilebileceği yanılsamasından uzak tutan, edebiyatı toplumsal seferberliğin dişında özerk bir şey olarak düşünmesini sağlayan da özerk kendiliğin ancak kayıpla kazanılabileceği sezgisidir" (Gürbilek 2004, 133-134).

Sonuçta Tanpınar tam da edebiyata ilişkin bu tutumu nedeniyle kendisinden sonraki modernist edebiyat çizgisini etkileyecektir. Unutmamak gerekiyor ki onu bu kadar önemli kılan edebiyat1nın içinden sorduğu sorulara verdiği yanıtlar değil; bizzat sorduğu soruların kendisidir.

\section{Ahmet Hamdi Tanpınar'dan Oğuz Atay'a Uzanan Süreklilikler ve Kırılmalar}

Dağılan imparatorluk ile yeni doğan cumhuriyetin her ikisini birden görebilen ara kuşağa mensup olan Tanpınar, gelenek ve modernlik çatışmasını daha yakıcı bir somutlukta yaşıyor; geleneğe dönmek gibi bir derdi olmasa da bu çatışmanın doğurduğu gerilimi romanlarının kendisine özgü dokusuyla dile getiriyordu. Oğuz Atay ise artık ara kuşak olamayacak kadar modernleşmeyi yaşayan ve benimseyen; aynı zamanda onunla çatışan bir yazardır. Oğuz Atay Batı'da karar kılmış bir tarihsel dönemecin yarattığı aydın kuşağının temsilcisidir. Ancak Batı'da karar kılmak ile Batı'yı tereddütsüz kabul etmek arasında bir nüans bulunuyor. Oğuz Atay tereddütsüz kabulün yaratacağı kimlik kaybı endişesi karşısında Batı'ya tabi olmaktan çok Batı ile eşit olmaya çalışan bir yazarlık tutumunu benimser. Gelenek ile modernlik arasında sıkışmış bir toplumun ürettiği klişeleri ironize etmek, bu tutumun ürettiği bir stratejidir. $\mathrm{Bu}$ strateji aynı zamanda kendi olmanın yoludur. Batı'ya tabiiyet kabul edilmeyeceğine ve Batılı olmaktan da vazgeçilemeyeceğine göre ancak orijinal bir konum yani sahicilik arayışı ile Batı'ya karşı tepkisel bir "çocukluktan" kurtulmak, olgunlaşabilmek mümkün olabilir: "Batı diyen insanların -çevremde- gittikçe bir ruh tembelliğine, düşünme tembelliği içine düştüğünü görüyorum. Orijinal düşünceden kaçmak ve kolayca hakl çıkmak için böyle oluyorlar sanki” (Atay 1987, 188). Atay'ın bütün romanları bu sahicilik arayışının peşinden koşan, toplumun yargılarıyla uyum sağlayamayan arada kalmışları anlatır. Toplum içinde Batılılaşmayı şekilci ve yüzeysel birtakım kodlara hapseden anlayışlara karşı varoluşçu felsefeyi kimlik meselesinin odağına yerleştiren bir tutum sergiler Oğuz Atay. Sonuçta Atay'ın sahicilik talebi toplumsal anlamdaki eklektizme ve ikiyüzlülüğe yönelik bir tepkiye dönüşür.

$\mathrm{Bu}$ tepkinin bir diğer boyutu da kendisinin de bir parçası olduğu aydınlara yöneliktir. $\mathrm{Bu}$ tepkiyi daha iyi anlayabilmek için Oğuz Atay'ın yazmaya başladığı 1960'ların sonu ve 1970’lerin başındaki tarihsel kırılmaya göz atmak gerekiyor. Erken Cumhuriyet dönemindeki yaşayan kimi aydınlar toplumu "biçimlendirmeye" çalışmış; hatta bu biçimlendirme çabalarının birtakım siyasi sonuçları olmuştur. 1930'lardaki Kadro deneyimi ile 1960'lardaki Yön Hareketi aslında bu tür aydın ideolojisinin tezahürleriydi. Çoğu durumda "zinde güçler" olarak tanımlanan ve kurucu ideolojinin temsilcisi gibi hareket eden bu zihniyet yapıs1 1970'lerle birlikte gücünü korusa da önemli bir kırılma yaşadı. Bu kırılmanın en önemli nedeni 12 Mart Darbesi ile birlikte 27 Mayıs Darbesi benzeri zinde güçler ittifakına (ordu, üniversite gençliği, aydınlar) dayalı yapısının artık değişmeye başlamasıydı. Kendisini toplumun bir sözcüsü olarak gören, devlet ile organik bir bütünleşme içinde varsayan aydınların önemli bir kısmı değişen iç ve dış konjonktürde artık ülkenin kaderini belirlemede asli unsur olmadıklarını hissetmeye başladılar. Kavrama süreci için 1980 sonrasını beklemek gerekecektir. Oğuz Atay bu süreci etraflıca teşhis eden bir habercidir. Oğuz Atay'ın öldükten sonra 1980'lerde keşfedilmesinin önemli sebeplerinden birisini burada aramak gerekir.

Aydınların zihniyet dünyasındaki değişimin ikinci önemli nedeni ise Türkiye’nin 1960 ve 
1970'li y1llarda sanayileşme ve şehirleşme ile birlikte kabuk değiştirme sürecine girmesiydi. Sosyal yapısı çeşitlenen ve zenginleşen bir ülkede artık 1930 ve 1940'larda olduğu gibi cemaatler halinde hareket eden, daha yekpare bir aydın hareketinden ve tutumundan bahsedilemez. 1950'lerin iki kutuplu ve daha az ideolojik temelli siyasal yapısı değişmeye başlamış; sağda ve solda yeni partilerin kurulduğu, var olan büyük partilerin daha ideolojik bir çizgiye evrildiği bir tablo ortaya çıkmıştı. Cumhuriyetin ilk yıllarında devlet ile organik bağa sahip olan aydınlarından farklı olarak; 1960'lı yıllarda daha çok çeviri eserin yayımlandığı, siyasal İslam, sosyalizm gibi önceden yasaklı ideolojilerin kendilerini yayın faaliyetleriyle daha açıktan ifade edebildiği bu ortamda siyasi düşünceler çeşitlendikçe dönemin aydınları da değişerek farklılaştılar.

Berna Moran, “Türk Romanına Eleştirel Bir Bakış” adlı kitabının ikinci cildinde, elbette istisnalar kaydıyla, Türk romanında 1950'lere kadar olan dönemde Batılılaşma sorunsalının bu dönemde yazılmış romanların temel izleğini oluşturduğunu, 1950 sonrasında ise toplumsal yapıdaki çatışmaların bu izleğin yerini almaya başladığını ileri sürer. Elbette bu tespit Batılılaşma meselesinin romanımızda artık gündem oluşturmadığı anlamına gelmiyor. Berna Moran'ın belirttiği gibi 1950 öncesi romancılarının çoğu "Batılılaşma sorunsalına eğildikleri ve sonuçlarını tartıştıkları yapıtlarıyla egemen ideolojiyi yeniden üretme çabasına katkıda bulunmaya devam ettiler" (Moran 1991, 12). Tanzimat romanlarının alafranga züppe tiplemeleri, modernleşmenin biçimci ve yüzeysel yansımalarına yönelik tepkilerin ürünüdür. Cumhuriyetin ilk yıllarında ise "ilericilik-gericilik" söylemi alafranga züppe eleştirisinin yerini almaya başlar. Ancak ilerleyen yıllarla birlikte yaşanan toplumsal değişim bu söylemin sürdürülebilir olmasını giderek zorlaştırmıştır. Kırdan kente göç olgusu, cılız da olsa gelişen toplumsal hareketler, üniversite gençliğinin ayrı bir siyasal güç olarak ortaya çıkması, yeni iktisadi bölüşüm meseleleri bu sosyal değişimin öne çıkan özellikleridir. Toplumu bütüncül ve organizmacı bir bakış açısından değerlendirmenin somut dayanakları da ortadan kalkmaktaydı. $\mathrm{Bu}$ değişimle birlikte toplumsal çatışma dinamikleri Türk romanının belirleyici izleklerinden biri haline gelmeye başlayacaktır. Artık Doğu-Batı, Batılılaşma, kimlik gibi meseleler bu parçalanmış toplumsal yapının içerisinde ele alınmaktadır.

Tanpınar'ın hissettiği ve sık sık ifade ettiği parçalanma ve yekpareliğin kayboluşu artık çok açık bir şekilde gerçekleşmeye başlamıştı. Kendisini devletin ve rejimin asli bir unsuru olarak görmeye alışmış aydınların önemli bir kesimi sistem ile karşı karşıya gelmeye başladıkça, bu onların hem yabancılaşmasına hem de hırçınlaşmasına yol açtı. Belki de bu sürecin en olumlu tarafı kendilerini devlet yerine ikame eden ve toplumu şekillendirmeye çalışan eski öncüllerinin tersine hem devleti hem de tarihi daha eleştirel bir tutumla sorgulamaya çalışan yeni bir aydınlar zümresinin ortaya çıkmasıydı. İşte Oğuz Atay'ın en ayırt edici özelliği olan ironisi, böylesi bir değişimin eseridir. Kuşaklararası iletişimsizlik, çatışan tarihsel palimpsest söylemler ve toplumsal yabancılaşma romanlarının odak noktasını oluşturur:

"Okulda ilk öğrendiğim gerçeklerden biri de babamın -sonra peder oldu- beni yanlışlıkla mektep yerine okula gönderdiği oldu. Önümüze alfabe adında anlaşılmaz bir kitap koydular. Babam, ona da elifba dedi. Okulla babamı uzlaştırmaya imkân yoktu. Bu garip kitapta, bizim kıllı̆gmiza pek benzemeyen bir biçimde giydirilmiş çocuklar, boyuna birbirlerine top attyorlardl. Hangi mahallede oturduklarını bilmediğim bu çocuklar, kumbaralarında -bizim evde böyle bir kutu yoktu- para biriktiriyorlar; babaları da-Ahmet Ăgabey kadar genç ve blyıksı adamlardı bunlar- onlara, çatana denen kaylklar allyordu. Bir de vatan denen bir 
şey vardı ki, çok iyi korunması gerekiyordu. Bizler, her sabah hep bir ă̆ızdan onu özümüzden çok sevdiğimizi, ant denilen bir şey içerek hayklrlyorduk" (Atay 1991, 76).

Oğuz Atay'ın karakterleri kendi içlerine dönen, içsel bir dünyadan yola çıkarak dışarıdaki hayatı sorgulayan kişilerdir. Onun kahramanları merkezin bir parçası olmadığı gibi toplumun bir sözcüsü olmayı da reddetmektedirler. Üstelik romanlarında kendisinin de içinde bulunduğu aydınlar dünyasını ironize etmekten sakınmaz. Kısacası Oğuz Atay, geçmişi ironize ederek bu tarihsel kopuşun yarattığı melankoliyi aşmaya ve anlamaya çalışır.

Tanpınar'da modernliğin getirdiği parçalanmışılı̆ın karşısında bir cemaat ruhu arayışı, bütüne ulaşma çabası oldukça belirgindir. Bir defa Tanpınar çoğu zaman bir cemaat kimliği adına konuşur, söylemsel öznesi “biz”dir. Bu yüzden Tanpınar'ın “Huzur” romanındaki Mümtaz ve İhsan gibi aydınlar Doğu-Batı ikileminde yargılayan ve toplum adına konuşan kişilerdir. İhsan, bireyi ve nihilizmi temsil eden Suat'1 tam da bu nedenle yadırgamaktadır: "Benim ferdin peşinde koşacak vaktim yok. Ben cemaat ile meşgulüm. Sürüden ayrlanın arkasından anası ağlasın!” (Tanpınar 2010, 301). Bu açıdan bakıldığında romanda birey olarak sadece Suat nihilist kimliği ile karşımıza çıkarken; Mümtaz, Nuran ve İhsan cemaat kimliğinden tam anlamıyla sıyrılamamışlardır.

Tanpınar'daki bütünlük arayışı, Atay'da yerini birey olabilme tutkusuna bırakır. Tanpınar'ın tasvir ettiği cemaatler halinde yaşanan İstanbul'u ile Atay'ın daha kalabalık, daha yabancılaşmış, daha karmaşık ama eski kozmopolitliğini yitirmiş daha tekdüze bir renge bürümüş İstanbul'u ya da Türkiye'si arasında epeyce bir farklılık bulunur. Tanpınar bütünlükçü toplum idealini ortaya koysa da bu idealin gerçekleşemeyeceğinin farkındaydı ve bu farkındalığın doğurduğu melankoliyle yazıyordu. Oğuz Atay'a gelindiğinde ise "biz” yerini çoktan "ben"e bırakmış ve kimlik modernleşme hesaplaşması artık birey üzerinden yapılmaya başlanmıştı. Tatjana Seyppel, Oğuz Atay üzerine yaptığı incelemede bu olgunun altını çizer: "Oğuz Atay'ın eserlerinin etrafında döndüğ̈̈ 'Ben' sorunu, onun edebi kişiliklerinin isimlerini seçişine de yansımıştır. Tehlikeli Oyunlar'ın baş kişisinin ismi Hikmet Benol, Tutunamayanlar'da Selim'in izlerini takip eden araştırmacının isimi de Turgut Özben'dir. Atay, bu Ben arayışının, ülkesinin yazarlarınca henüz ele alınmadiğını düşünmektedir" (Seyppel 1989, 34).

Atay'ın roman karakterleri, içinde yaşadıkları toplumsal düzen ile barışık olmayan ve bu yüzden toplum dışına itilen kişilerdir. Tanpınar'ın aksine Atay'ın kahramanları (belki de antikahramanları demek daha doğru olacaktır) toplum değil kendi iç dünyaları adına konuşurlar. Doğu-Batı sorununda Mümtaz'ın ve İhsan'ın savunduğu estetik ideoloji aynı zamanda toplumsal bir önermedir. Ancak “Tutunamayanlar” romanının başkarakterleri olan Turgut ve Selim için sanat ve estetik, anlamsız hayata ve sahteliğe karşı bireysel direnişi ifade eder. Bu direniş aynı zamanda bir makinenin kendisine benzetilen toplumsal düzene karşı anti konformist bir tutuma dönüşür. Düzen içinde bir yeri ve geleceği olan Turgut'un, kendini asarak intihar eden tutunamayan arkadaşı Selim'in ardından yaptığı vicdan muhasebesi gibi:

"Şimdi yanımda olsaydın, bütün bu meseleleri tartışsaydık. Birçok meseleyi askıda bırakıp gittin. Beni bıraktın bu makinenin çarkları arasında. Ben de dişlilere ceketimi kaptırdım. Eteğimin ucundan bağlandim bu düzene. Ceketi çıkarmadan olmaz. Ceket çıkarma talimatı da verilmedi daha. Çıkar üstündekileri, kurtul bu düzenden. Olmaz Selim: çırılçılak kalırım sonra. Tutunacak bir yer bulamam sonra. Düşünceler göklere yükseliyor, fakat vücut toprağa bağll” (Atay 1991, 311-312). 
“Tutunamayanlar"1n en önemli teması iletişimsizlik üzerinedir. Gerek kuşaklar arası gerekse bireyler arası kimsenin kimseyi dinlemediği, anlamaya çalışmadığı bir iletişimsizlik platformudur söz konusu olan. Diller bile yabancıdır birbirine. Bir yanda Osmanlıca bir yanda öz Türkçe metinlerin bir arada bulunduğu bu düzlemde kimse birbirini tam olarak anlayamaz. Hâlbuki "Huzur"da Mümtaz ve Suat'ın arasında uçurumlar olsa da en azından tartışabiliyorlar ve ne demek istediklerini birbirine anlatabiliyorlardır. Oğuz Atay'da ise hep konuşan; ama bir türlü birbirini anlamayan kalabalık içindeki herkes birbirinin sesine, çığlığına yabancıdır. Bunu aşabilmenin yolu ise empati duygusuna sahip olabilmekten geçer: "cennet muhallebiden duvarlar demek değildir sayın yetkili cennet insanların birbirlerini dinlemeleri demektir birbirlerine aldırmaları birbirlerinin farkında olmaları demektir" (Atay 1991, 519).

Atay'da samimiyet ve sahicilik arayışı ve derdi sahici bir derttir. Sahte ve ikiyüzlü bir düzende sahicilik Atay'ın tutunamayan karakterlerinin tek hayat dalıdır. Bu dal kırıldığında "Sahte olmaktansa yaşamamak iyidir" diyerek ya intihara ya da deliliğe sürüklenirler (Atay 1991, 455). Taklit, bayağı ve yüzeysel olan bir hayatta sahicilik tek varoluş yoludur onlar için. "Tehlikeli Oyunlar"ın başkahramanı Hikmet Benol sahiciliğin yaşamasına izin verilmeyen ve gerçeğin boğucu olduğu bir ülkede var olabilmenin yolunun hayatı bir oyuna çevirmekten geçtiğine karar vermiştir. Hikmet Benol, Atay'ın bütün diğer kahramanlarının ortak derdini yani gölgede kalmayı, önemsenmemeyi kısacası ikinci sınıf insan olmayı reddettiği için de ülke denilen bu büyük tiyatro sahnesinde kendisi olabilmenin telaşı içerisindedir.

Oğuz Atay'da varoluşsal krizin tek reçetesi olan sahicilik talebiyle birlikte bir şeyin daha önemli yer tuttuğu hemen fark edilir: "Acelesi olmak”. Acelesi olmak hem kişisel alandaki tamamlanmamışlık duygusuyla hem de toplumsal anlamda bir taşra ülkesi olmanın getirdiği kaygılarla örtüşür. "Tehlikeli Oyunlar"ın başkarakteri Hikmet Benol'un soyadı bile bu yarım kalmış benliğe göndermede bulunur. Akıl hastanesinde intiharla biten bir trajedi aynı zamanda toplumsal olarak azgelişmişlik ile yakından irtibatlıdır. Terakki, medeniyet gibi sıfatlarla tanımlanan ve kurtuluşa giden yolun tek aracı olarak görülen Avrupa trenine yetişme endişesi; aceleye ve telaşa dönüşmüş bir ülkenin aydınıdır Oğuz Atay. Her daim acelesi olanların her daim geç kalanların hikâyesini anlatır romanlarında. Son anda da olsa vagonlardan birine yetişebilmek için can hıraş bir şekilde koşan bir çocuğun telaşıdır söz konusu olan:

\section{"Herkesin canına okuyacağız. Yabancılardan, geri kalmışlı̆̆ımızın acı- sını çıkaracağız.'(...) Acelemiz var doktor: Yaşanmamış bütün olayları yeniden sahneye koymak gibi tarihsel bir görevimiz var. Avrupa'yl yüz- yıllarca geriden izlemekten usandık artık. Önce Fransa İhtilalini yapaca- $\breve{g} l z "$ (Atay 2008, 337).}

Oğuz Atay'da dile gelen bu aceleci Avrupa'ya yetişme telaşı, aynı zamanda bir karabasana dönüşür. Modernleşme yoluna geç girmiş toplumların bu telaşı hızla alınmış yolların yarattığı sancilarla boğuşmak anlamına da gelmektedir. Oğuz Atay bu durumu ulusal alegori çerçevesinde eleştirel ve ironik bir biçimle anlatır.

Oğuz Atay konformizm karşıtlığı ve yabancılaşma üzerinden yeni bir birey kavramı üzerine eğilmekte; kolektif kimlikler ile birey arasındaki çatışmayı merkeze oturtmaktadır. Oğuz Atay kafası karışanların romanını yazmıştır. Ama diğer yandan ironi silahıyla toplumsal düzene sert bir eleştiri getirir. İroninin gücü yazarın kimlikler üstü bir konum alması ile pekişir ancak. Oğuz Atay bütün romanlarında bu tutumunu sahici bir varoluşsal problem haline getirebilmektedir. Onu özgün kılan sadece o güne kadar Türk edebiyatında denenmemiş olan biçimsel yenilikleri gerçekleştirmiş olması değil; düşünsel olarak geleneksel kültürel izleklerden radikal bir kopuşu 
göze almasıdır. O romanlarında birey-cemaat çatışmasını, kültürel kimlik krizini, varoluşsal çıkışsızlıkları, toplumsal ve kültürel kodları kılı kırk yararcasına ironik ve hüzünlü bir sesle dile getirir. Onun kitapları sadece dışlanmışların, ötekilerin hikâyesi değil aynı zamanda geçmişi ve bugünü bambaşka bir pencereden okumanın ve anlamaya çalışmanın ta kendisidir.

\section{Sonuç}

Doğu-Batı meselesi Ahmet Hamdi Tanpınar ve Oğuz Atay'ın metinlerinde merkezi bir izlek olmasına rağmen bir ölüm kalım mücadelesi veya varoluş meselesi olarak ele alınmaz. Osmanlı İmparatorluğu'nun son yıllarında ortaya çıkmış roman yazarları biraz daha acemice bir yolla, erken cumhuriyet devri yazarları ise bu meseleyi bir medeniyet krizi şeklinde ele almışlardır. Modernleşme sürecinin yarattı̆̆ çalkantılar, toplumsal değişimin getirdiği endişeler genelde Doğu ve Batı medeniyetlerinin "karş̧ karşıya gelmesi" şeklinde işlendi bu yazarların romanlarında. Tanpınar ve Atay'da ise Doğu-Batı ya da kimlik sorunları bir tez olarak, bir tartışma ve çözüm konusu olarak romana dahil olmaz. Roman kurgularının bir parçası olarak bir fikir yüküne değil; onu derinleştiren bir unsur haline gelir.

Her biri cumhuriyet döneminin değişen tarihsel kırılma noktalarına denk gelen Tanpınar ve Atay'ın Doğu-Batı meselesine yaklaşımları Türk edebiyatında özel bir yere tekabül ediyor. Bu farklılık her şeyden önce bu yazarların meseleye soğukkanlı yaklaşmalarıyla ilişkilidir. $\mathrm{Bu}$ yüzden medeniyetler arasında varsayılan çatışmaya taraf olma veya bu çatışmanın sentezci bir yolla çözümlenmesi kolaycılığına kaçmazlar. Bu yazarlar için Doğu-Batı meselesi "çözümsüzdür" her şeyden önce. Çözüm arar gibi yapıldığında bile bir sonuca ulaşmayı kabul etmezler aslında. Bu meselenin varsayılan taraflarından birisine yaslanarak veya sentez fikriyle üstesinden gelinemeyecek kadar karmaşık ve müdahale kabul etmeyen bir yapısı olduğunu; ancak hayatın kendi doğal seyri içerisinde çıkış yolunun bulunabileceğini fark etmişlerdi.

Sonuç olarak onları benzer kılan Doğu-Batı meselesine üsten bakabilmeyi başarabilmiş olmalarıdır. Bu üst bakış Doğu-Batı meselesinin sadece bir siyasal ya da kültürel kimlik meselesi olarak değil bir estetik sorun olarak görmeye de götürür onları. Bu yazarlar için DoğuBatı meselesi diye tasnif edilen şeyler hayatın sıradanlaşması ve yüzeyselleşmesine karşı (tepkisel bir gelenekçiliğe karşı) hem yeniyi ve kaçınılmaz olanı komplekssiz bir şekilde kabul etmekle hem de yitip giden geçmişi bir zenginlik olarak (tüketim kalıplarına indirgenmiş sı ğ bir Batılılaşmaya karşı) kabul edebilmekten geçer. Bu nedenle Doğu-Batı meselesi bir çarpışma ya da varlık yokluk mücadelesi olmaktan çıkar, bir kendini tanıma ya da hesaplaşma konusuna dönüşür. Böylesi bir geçmiş ve gelenek değerlendirmesi bu yazarları hem özcü tutumlardan uzak tutarak onları kimlik konusunda basit, kolaycı klişeleri tekrarlamaktan alıkoymuş; hem de yitip giden geçmiş ile bugün arasında daha sağlıklı ve soğukkanlı bir düşünme biçimi geliştirmelerini sağlamıştır. 


\section{KAYNAKÇA}

Atay O. $\left(2008^{20}\right)$. Tehlikeli Oyunlar. İstanbul 2008.

Atay O. (19917). Tutunamayanlar. İstanbul 1991.

Atay O. (1987). Günlük. İstanbul 1987.

Ayvaz E. (2006). “Sonradan Gelenin Tanıklı̆̆gı”. Toplumbilim Dergisi 20 (2006) 153-163.

Ersanlı Behar B. (1995²). Iktidar ve Tarih, Türkiye'de “Resmi Tarih” Tezinin Oluşumu (1929-1937).

İstanbul 1995.

Gürbilek N. (2004). Kör Ayna, Kayıp Şark: Edebiyat ve Endişe. İstanbul 2004.

Maszák-Szegedy M. (2001). Literary Canons: National and International. Budapest 2001.

Moran B. (1991²). Türk Romanına Eleştirel Bir Bakış. Cilt II. İstanbul 1991.

Tanpınar A. H. (2010 $\left.{ }^{18}\right)$. Huzur. İstanbul 2010.

Tanpınar A. H. (2008a $\left.{ }^{24}\right)$. Beş Şehir. İstanbul 2008.

Tanpınar A. H. $\left(2008 b^{3}\right)$. Günlüklerinin Işı̆̆ında Tanpınar'la Baş Başa. Ed. İnci Enginün-Zeynep Kerman. İstanbul 2008.

Tanpınar A. H. (2005a $a^{7}$. Mahur Beste. İstanbul 2005.

Tanpınar A. H. (2005b $\left.{ }^{10}\right)$. Saatleri Ayarlama Enstitüsü. İstanbul 2005.

Tanpınar A. H. (2005c ${ }^{4}$ ). Yaşadı̆̆ım Gibi. İstanbul 2005.

Seyppel T. (1989). Oğuz Atay'ın Dünyası. Çev. Tanıl Bora. İstanbul 1989. 